\title{
Pemodelan Jumlah Kasus Hiv dan Aids di Kota Surabaya Menggunakan Bivariate Generalized Poisson Regression
}

\author{
Suprianto Simanjuntak dan Purhadi \\ Departemen Statistika, Fakultas MIPA, Institut Teknologi Sepuluh Nopember (ITS) \\ e-mail: supriantojuntak@gmail.com,purhadi@statistika.its.ac.id
}

\begin{abstract}
Abstrak-HIV dan AIDS merupakan penyakit yang menjadi perhatian di Indonesia, jumlah kasus HIV dan AIDS sejak 1987 sampai 2014 menunjukkan bahwa Provinsi Jawa Timur berada pada urutan ke dua dengan jumlah kasus HIV dan AIDS tertinggi di Indonesia. Kota Surabaya merupakan kota yang memliki jumlah kasus baru HIV dan AIDS terbanyak di Provinsi Jawa Timur. Jumlah kasus HIV di Kota Surabaya memiliki hubungan linier dengan jumlah kasus AIDS, sehingga disebut bivariate. Kedua jumlah tersebut termasuk variabel random yang memiliki varians lebih besar dari nilai rata-ratanya. Ukuran ini disebut overdispersi. Oleh karenanya, kedua variabel tersebut tidak dapat didekati dengan distribusi Poisson yang memiliki nilai varians dan rata-rata yang sama. Pendekatan distribusi lain yang memungkinkan yaitu bivariate generalized Poisson. Dalam rangka mengidentifikasi variabel-variabel prediktor yang berpengaruh signifikan terhadap jumlah kasus HIV dan AIDS, analisis regresi yang diterapkan juga disesuaikan dengan distribusi variabelvariabel respon. Meng-aplikasikan bivariate generalized Poisson regression, berdasarkan hasil analisis, diperoleh simpulan bahwa faktor yang berpengaruh signifikan terhadap jumlah kasus HIV adalah persentase penduduk pengguna kondom, persentase penduduk yang tamat SMA, persentase penduduk kelompok umur 25-29 tahun dan persentase kegiatan penyuluhan kesehatan masyarakat. Faktor yang berpengaruh signifikan terhadap jumlah kasus AIDS adalah persentase penduduk yang memiliki jaminan kesehatan masyarakat miskin. Model terbaik yang diperoleh adalah model yang melibatkan semua variabel prediktor dengan nilai AIC sebesar 220,038.
\end{abstract}

Kata Kunci---AIDS, Bivariate Generalized Poisson Regression, HIV.

\section{PENDAHULUAN}

$\mathrm{H}^{\mathrm{v}}$ IV dan AIDS merupakan penyakit yang menjadi perhatian di Indonesia, HIV dan AIDS di Indonesia pertama kali ditemukan di Provinsi Bali tahun 1987. Hingga saat ini HIV dan AIDS sudah menyebar di 386 kabupaten/kota di seluruh provinsi di Indonesia. Berdasarkan laporan provinsi, jumlah kasus infeksi HIV yang dilaporkan sejak 1987 sampai september 2014 yang terbanyak adalah DKI Jakarta dengan 32.782 kasus. Lima provinsi dengan kasus HIV terbanyak adalah Provinsi DKI Jakarta, Jawa Timur, Papua, Jawa Barat dan Bali. Lima provinsi dengan kasus AIDS terbanyak adalah Provinsi Papua, Jawa Timur, DKI Jakarta, Bali dan Jawa Barat [1].

Berdasarkan uraian tersebut Provinsi Jawa Timur selalu masuk ke dalam lima besar provinsi dengan jumlah kasus HIV dan AIDS terbanyak sejak 1987 sampai september 2014. Di antara 38 kabupaten/kota yang ada di Provinsi Jawa Timur, Kota Surabaya merupakan daerah dengan jumlah kasus baru HIV dan AIDS terbanyak, pada tahun 2015 ditemukan 652 kasus HIV dan 281 kasus AIDS di Surabaya [2]. Jumlah kasus HIV dan jumlah kasus AIDS di Kota Surabaya berupa data jumlahan yang diduga saling berkorelasi, serta mengalami kasus overdispersi atau underdispersi sehingga dapat dianalisis dengan metode Bivariate Generalized Poisson Regression (BGPR). Penelitian sebelumnya yang meng-gunakan metode BGPR [3], [4] menghasilkan kesimpulan bahwa metode BGPR dapat menghasilkan model terbaik terhadap sepasang data count yang saling berkorelasi, berdistribusi bivariate Poisson dan mengalami kasus overdispersi.

Berdasarkan uraian diatas, pada penelitian ini jumlah kasus HIV dan jumlah kasus AIDS di Kota Surabaya dianalisis dengan menggunakan bivariate generalized Poisson regression. Tujuan penelitian ini adalah mengidentifikasi faktor-faktor yang mempengaruhi jumlah kasus HIV dan jumlah kasus AIDS dan mendapatkan model terbaik serta faktor yang mempengaruhi jumlah kasus HIV dan jumlah kasus AIDS di Kota Surabaya.

\section{TINJAUAN PUSTAKA}

\section{A. Bivariate Generalized Poisson Regression}

Bivariate generalized Poisson regression merupakan pengembangan dari bivariate Poisson regression, dimana datanya mengalami kasus overdispersi ataupun underdispersi. BGPR juga digunakan untuk memodelkan sepasang data count yang memiliki korelasi dengan variabel prediktor yang diduga mempengaruhinya. Sebelum pemodelan BGPR dilakukan, maka terlebih dahulu dilakukan uji distribusi bivariate generalized Poisson. Misalkan $\mathrm{N}_{1}, \mathrm{~N}_{2}, \mathrm{~N}_{3}$ merupakan variabel acak yang saling bebas, masing-masing berdistribusi generalized Poisson serta diberikan variabel acak $Y_{1}=N_{1}+N_{3}$ dan $Y_{2}=N_{2}+N_{3}$ maka fungsi peluang bersamanya sebagai persamaan 1 [5].

$f\left(y_{1}, y_{2}\right)=\mu_{0} \mu_{1} \mu_{2} \exp \left\{-\left(\mu_{0}+\mu_{1}+\mu_{2}\right)-y_{1} \alpha_{1}-y_{2} \alpha_{2}\right\} . A . B$ dimana:

$$
\begin{aligned}
& y_{1}, y_{2}=0,1,2, \ldots \\
& A=\sum_{k=0}^{\min (y 1, y 2)} \frac{\left(\mu_{1}+\left(y_{1}-k\right)\right)^{y_{1}-k-1}}{\left(y_{1}-k\right) !\left(y_{2}-k\right) ! k !} \\
& B=\left(\mu_{2}+\left(y_{2}-k\right)\right)^{y_{2}-k-1}\left(\mu_{0}+k \alpha_{0}\right)^{k-1} \exp \left\{k\left(\alpha_{1}+\alpha_{2}-\alpha_{0}\right)\right\}
\end{aligned}
$$

Untuk mengetahui apakah variabel $Y_{1}$ dan $Y_{2}$ mengikuti distribusi bivariate generalized Poisson, maka dilakukan uji distribusi bivariate generalized Poisson menggunakan Crockett's test dengan hipotesis sebagai berikut:

$\mathrm{H}_{0}$ : variabel respon $Y_{1}$ dan $Y_{2}$ mengikuti distribusi $b i$ variate generalized Poisson

$\mathrm{H}_{1}$ : variabel respon $Y_{1}$ dan $Y_{2}$ tidak mengikuti distribusi bivariate generalized Poisson 
penentuan nilai Crockett's test dilakukan dengan perhitungan sebagai berikut:

$$
T=\mathbf{Z}^{\prime} \hat{\mathbf{V}}^{-1} \mathbf{Z}
$$

dimana:

$$
\begin{gathered}
\mathbf{Z}^{\prime}=\left[\begin{array}{ll}
Z_{Y_{1}} & Z_{Y_{2}}
\end{array}\right] ; Z_{h}=\operatorname{var}\left(Y_{h}\right)-\bar{Y}_{h}, h=1,2 \text { dan } \\
\hat{\mathbf{V}}=\frac{2}{n}\left[\begin{array}{cc}
\hat{\lambda}_{1} & \hat{\lambda}_{12} \\
\hat{\lambda}_{21} & \hat{\lambda}_{2}
\end{array}\right] ; n=1,2 ; \hat{\lambda}_{h}=\operatorname{var}\left(Y_{h}\right) ; \\
\hat{\lambda}_{g h}=\operatorname{cov}\left(Y_{g}, Y_{h}\right) ; g, h=1,2 ; g \neq h
\end{gathered}
$$

Tolak $\mathrm{H}_{0}$ jika $T>\chi_{(n, \alpha)}^{2}$

Jika $Y_{1 i}, Y_{2 i}: B G P\left(\mu_{1 i}, \mu_{2 i}, \alpha_{1}, \alpha_{2}\right)$ maka model BGPR didefenisikan sebagai berikut:

$$
\begin{aligned}
& \ln \left(\mu_{j i}\right)=\mathbf{x}_{\mathbf{i}}^{\prime} \boldsymbol{\beta}_{\mathbf{j}}=\beta_{j 0}+\beta_{j 1} x_{1 i}+\beta_{j 2} x_{2 i}+\mathrm{L}+\beta_{j k} x_{k i} \\
& \mu_{j i}=\exp \left(\mathbf{x}_{\mathbf{i}}^{\prime} \boldsymbol{\beta}_{\mathbf{j}}\right)=\exp \left(\beta_{j 0}+\beta_{j 1} x_{1 i}+\beta_{j 2} x_{2 i}+\mathrm{L}+\beta_{j k} x_{k i}\right)
\end{aligned}
$$

dimana:

$\mathbf{x}_{\mathbf{i}}=\left[\begin{array}{lllll}1 & x_{1 i} & x_{2 i} & \mathrm{~L} & x_{k i}\end{array}\right]^{\prime}$

$\boldsymbol{\beta}_{\mathbf{j}}=\left[\begin{array}{lllll}\beta_{j 0} & \beta_{j 1} & \beta_{j 2} & \mathrm{~L} & \beta_{j k}\end{array}\right]^{\prime} ; j=1,2$

$i=1,2, \ldots, n$ (banyak pengamatan)

1) Penaksiran Parameter Bivariate Generalized Poisson Regression

Pada model BGPR parameternya ditaksir dengan menggunakan metode Maximum Likelihood Estimation (MLE) dengan fungsi likelihood dari BGPR adalah sebagai berikut:

$L\left(\mu_{0}, \mu_{1 i}, \mu_{2 i}, \alpha_{1}, \alpha_{2}, \alpha_{0}, i=1,2, \ldots, n\right)=\prod_{i=1}^{n} \mu_{0} \mu_{1 i} \mu_{2 i} . A_{1} \sum_{k=0}^{\min \left(y_{1 i}, y_{2 i}\right)} A_{2} . A_{3}$

dimana:

$$
\begin{aligned}
& A_{1}=\exp \left\{-\left(\mu_{0}+\mu_{1 i}+\mu_{2 i}\right)-y_{1 i} \alpha_{1}-y_{2 i} \alpha_{2}\right\} \\
& A_{2}=\frac{\left(\mu_{1 i}+\left(\mu_{1 i}-k\right) \alpha_{1}\right)^{y_{1}-k-1}}{\left(y_{1 i}-k\right) !} \frac{\left(\mu_{2 i}+\left(\mu_{2 i}-k\right) \alpha_{2}\right)^{y_{2 i}-k-1}}{\left(y_{2 i}-k\right) !} \frac{\left(\mu_{0}+k \alpha_{0}\right)^{k-1}}{k !}
\end{aligned}
$$$$
A_{3}=\exp \left(k\left(\alpha_{1}+\alpha_{2}-\alpha_{0}\right)\right)
$$

kemudian dibentuk fungsi ln likelihood dari persamaan 5 dan diturunkan terhadap masing-masing parameter. Berdasarkan hasil turunan pertama terhadap semua parameter diperoleh hasil persamaan yang eksplisit, sehingga dapat diselesaikan dengan optimasi Nelder-Mead.

\section{2) Pengujian Hipotesis Parameter Bivariate Generalized \\ Poisson Regression}

Pengujian serentak parameter pada BGPR dilakukan untuk mengetahui apakah parameter $\alpha$ dan $\beta$ signifikan terhadap model secara bersama-sama, dengan hipotesis sebagai berikut:

$\mathrm{H}_{0}: \beta_{j 1}=\beta_{j 2}=\mathrm{L} \beta_{j k}=0$ dan $\alpha_{1}=\alpha_{2}=0$

$\mathrm{H}_{1}$ : minimal ada satu dari $\beta_{j l} \neq 0$ dan $\alpha_{j} \neq 0 ; j=1,2$;

$$
l=1,2, \ldots, k
$$

Statistik uji yang digunakan untuk pengujian serentak adalah sebagai berikut:

$$
D(\hat{\boldsymbol{\beta}}) \sim-2 \ln \left(\frac{L(\hat{\omega})}{L(\hat{\Omega})}\right)=2 \ln (L(\hat{\Omega})-L(\hat{\omega})) \sim \chi_{v}^{2}
$$

$D(\hat{\boldsymbol{\beta}})$ merupakan pendekatan distribusi Chi-Square dengan derajat bebas $v$ (jumlah parameter dibawah populasi dikurangi jumlah parameter dibawah hipotesis). Tolak $\mathrm{H}_{0}$ jika
$D(\hat{\boldsymbol{\beta}})>\chi_{(\alpha, v)}^{2}$ [6]. Jika pada pengujian serentak diperoleh hasil tolak $\mathrm{H}_{0}$, maka analsis dilanjutkan ke pengujian parameter secara parsial dengan hipotesis sebagai berikut:

a). Parameter $\alpha$

$$
\begin{aligned}
& \mathrm{H}_{0}: \alpha_{j}=0 \\
& \mathrm{H}_{1}: \alpha_{j} \neq 0 ; j=1,2 \\
& \text { Statistik Uji: } \\
& Z_{h i t}=\frac{\hat{\alpha}_{j}}{S E\left(\hat{\alpha}_{j}\right)}
\end{aligned}
$$

b). Parameter $\beta$

$$
\begin{aligned}
& \mathrm{H}_{0}: \beta_{j l}=0 \\
& \mathrm{H}_{1}: \beta_{j l} \neq 0 ; j=1,2 \text { dan } l=1,2, \ldots, k
\end{aligned}
$$

Statistik Uji:

$$
Z_{h i t}=\frac{\hat{\beta}_{j l}}{S E\left(\hat{\beta}_{j l}\right)}
$$

untuk pengujian $\alpha$ dan $\beta$ tolak $\mathrm{H}_{0}$ jika $\left|Z_{h i t}\right|>Z_{\frac{\alpha}{2}}$ dengan $\alpha$ merupakan taraf signifikansi yang digunakan.

\section{B. Uji Korelasi dan Pemeriksaan Multikolinieritas}

Salah satu syarat pada BPGR adalah adanya hubungan linier antar variabel respon, pengujian korelasi untuk variabel respon dilakukan dengan hipotesis sebagai berikut:

$\mathrm{H}_{0}$ : Tidak ada hubungan antara $Y_{1}$ dan $Y_{2}$

$\mathrm{H}_{1}$ : Terdapat hubungan antara $Y_{1}$ dan $Y_{2}$

Statistik uji yang digunakan untuk uji korelasi adalah sebagai berikut:

$$
t=\frac{r_{Y_{1}, Y_{2}} \sqrt{n-2}}{\sqrt{1-\left(r_{Y_{1}, Y_{2}}\right)^{2}}}
$$

Tolak $\mathrm{H}_{0}$ jika $\left|t_{h i t}\right|>t_{\left(\frac{\alpha}{2}, n-2\right)}$

Pendeteksian adanya kasus multikolinieritas adalah dengan memperhatikan nilai Variance Inflation Factor (VIF) [7]. Nilai VIF yang lebih dari 10 mengindikasikan terjadi multikolinieritas antar variabel prediktor, VIF didefenisikan sebagai persamaan berikut:

$$
V I F=\frac{1}{1-R_{j}^{2}}, j=1,2, \ldots, k
$$

$R_{j}^{2}$ adalah nilai koefisien determinasi prediktor ke-j dengan prediktor lainnya.

\section{Pemeriksaan Equidispersi}

Pada regresi Poisson terdapat asumsi yang harus dipenuhi yaitu equidispersi, equidispersi merupakan kondisi dimana nilai rata-rata dari variabel respon sama dengan nilai variansnya. Jika terdapat nilai rata-rata lebih besar dari nilai varians, maka terjadi kasus overdispersi. Overdispersi nilai dispersi pearson chi-square atau deviance yang jika dibagi dengan derajat bebas diperoleh nilai lebih besar dari satu [8].

\section{Pemilihan Model Terbaik}

Pada penelitian ini pemilihan model terbaik dilakukan dengan menggunakan Akaike's Information Criterion (AIC). 
Perhitungan nilai AIC untuk model regresi multivariat adalah sebagai berikut [9].

$$
A I C=n \ln \left(\left|\hat{\Sigma}_{\mathrm{d}}\right|\right)-2 j k
$$

dimana:

$n$ = banyaknya pengamatan

$\hat{\Sigma}_{\mathbf{d}}=\frac{1}{n} \sum_{i=1}^{n} \boldsymbol{\varepsilon}_{i}^{T} \boldsymbol{\varepsilon}_{i}$

$j \quad$ = banyaknya variabel respon

$k$ = banyaknya variabel prediktor

\section{E. HIV dan AIDS}

Human Immunodeficiency Virus (HIV) adalah sejenis virus yang menyerang atau menginfeksi sel darah putih yang meyebabkan turunnya kekebalan tubuh manusia, sehingga orang yang terserang penyakit tersebut tidak dapat melawan berbagai jenis penyakit yang menyerang tubuhnya. Menurunnya kekebalan tubuh akibat HIV berdampak pada mudahnya terkena berbagai penyakit infeksi (Infeksi oportunistik) yang sering berakibat fatal. Acquired Immune Defeciency Syndrom (AIDS) adalah sekumpulan gejala penyakit yang timbul akibat turunnya kekebalan tubuh yang disebabkan oleh infeksi HIV.

\section{METODOLOGI PENELITIAN}

\section{A. Sumber Data}

Data yang digunakan adalah data sekunder yang diperoleh dari Publikasi Dinas Kesehatan Kota Surabaya pada tahun 2013. Jumlah unit pengamatan sebanyak 31 unit pengamatan yaitu 31 kecamatan yang ada di Kota Surabaya.

\section{B. Variabel Penelitian}

Adapun variabel penelitian yang digunakan dalam penelitian ini terdiri dari variabel respon $(\mathrm{Y})$ dan variabel prediktor $(\mathrm{X})$ yang ditunjukkan pada Tabel 1.

\section{Langkah Analisis}

Langkah analisis yang dilakukan dalam penelitian ini adalah sebagai berikut:

Tabel 1.

Variabel Penelitian

\begin{tabular}{cll}
\hline \hline Variabel & \multicolumn{1}{c}{ Keterangan } & Tipe \\
& & \\
\hline $\mathrm{Y}_{1}$ & Jumlah Kasus baru HIV. & Count \\
$\mathrm{Y}_{2}$ & Jumlah Kasus baru AIDS. & Count \\
$\mathrm{X}_{1}$ & Persentase penduduk pengguna kondom. & Kontinu \\
$\mathrm{X}_{2}$ & Persentase penduduk yang tamat SMA. & Kontinu \\
$\mathrm{X}_{3}$ & Persentase penduduk kelompok umur 25-29 & Kontinu \\
& tahun. & \\
$\mathrm{X}_{4}$ & Persentase penduduk yang memiliki jaminan & \multirow{2}{*}{ Kontinu } \\
& kesehatan masyarakat miskin. & \\
$\mathrm{X}_{5}$ & $\begin{array}{l}\text { Persentase kegiatan penyuluhan kesehatan } \\
\text { masyarakat. }\end{array}$ & Kontinu \\
\hline \hline
\end{tabular}

1. Mendeskripsikan variabel respon dan prediktor dengan dua cara, yaitu dengan menggunakan tabel serta peta tematik yang dibagi menjadi tiga kategori berdasarkan klasifikasi natural breaks.

2. Identifikasi variabel respon dan prediktor, dengan langkahlangkah sebagai berikut:

a. Melakukan uji korelasi antar variabel respon, yaitu jumlah kasus HIV dan AIDS.

b. Melakukan uji distribusi bivariate generalized Poisson pada variabel respon dengan menggunakan Crockett's test.

c. Pemeriksaan equidispersi pada variabel respon, yaitu jumlah kasus HIV dan AIDS.

d. Pemeriksaan multikolinieritas pada variabel prediktor yang diduga mempengaruhi jumlah kasus HIV dan AIDS dengan menggunakan kriteria VIF.

3. Menentukan model terbaik dari all possible models berdasarkan nilai AIC terkecil.

4. Pemodelan jumlah kasus HIV dan AIDS menggunakan bivariate generalized Poisson regression pada model terbaik, dengan langkah sebagai berikut:

a. Penaksiran parameter model BGPR dengan menggunakan Maximum Likelihood Estimation (MLE).

b. Melakukan pengujian signifikansi parameter secara serentak dan parsial.

c. Interpretasi Model.

\section{ANALISIS DAN PEMBAHASAN}

\section{A. Deskripsi Jumlah Kasus HIV dan AIDS di Kota Surabaya}

Jumlah kasus HIV di kota surabaya terus meningkat dari tahun 2013-2015, sedangkan jumlah kasus AIDS dikota Surabaya dari tahun 2013-2015 mengalami fluktuasi. Rata-rata jumlah kasus HIV di setiap kecamatan di Kota Surabaya pada tahun 2014 adalah 17 kasus, sedangkan rata-rata jumlah kasus AIDS adalah 11 kasus. Rata-rata jumlah kasus HIV di setiap kecamatan di Kota Surabaya pada tahun 2015 adalah 20 kasus, sedangkan rata-rata jumlah kasus AIDS sebanyak 8 kasus. Rata-rata jumlah kasus HIV dan AIDS di setiap kecamatan di Kota Surabaya disajikan pada Gambar 1.

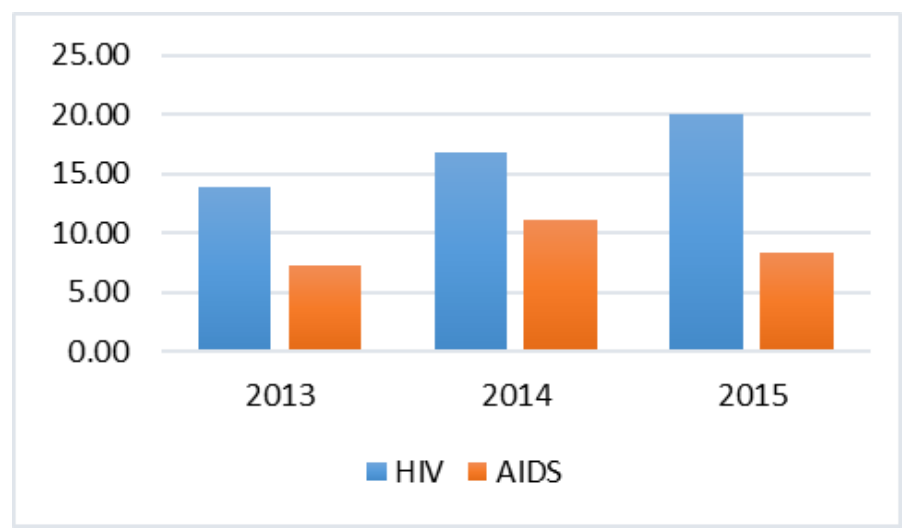

Gambar 1 Rata-rata Jumlah Kasus HIV dan AIDS di Kota Surabaya Tahun 2013-2015. 
Pada tahun 2013 rata-rata jumlah kasus HIV di setiap kecamatan yang ada di Kota Surabaya sebanyak 14 kasus. Kasus HIV terbanyak adalah 114 kasus yang berada di Kecamatan Sawahan sementara di Kecamatan Lakar Santri tidak ada kasus HIV. Kecamatan Pabean Cantikan merupakan kecamatan dengan persentase pengguna kondom tertinggi yaitu sebesar $1,2432 \%$ dari jumlah penduduknya, sementara terendah adalah Kecamatan Asemrowo sebesar 0,0046\%. Kecamatan Tegalsari merupakan kecamatan dengan persentase penduduk yang tamat SMA tertinggi sebesar 53,22\%, sementara terendah berada di Kecamatan Asemrowo sebesar 22,08\%. Persentase penduduk kelompok umur 25-29 tahun tertinggi berada di Kecamatan Tandes sebesar $11,273 \%$, sementara terendah berada di kecamatan Pakal sebesar 7,777\%. Kecamatan dengan persentase penduduk yang memiliki jaminan kesehatan masyarakat miskin tertinggi berada di Kecamatan Semampir dan terendah di Kecamatan Tenggilis. Kecamatan dengan persentase kegiatan penyuluhan kesehatan masyarakat tertinggi berada di Kecamatan Tegalsari sebesar 3,242\%, sementara terendah berada di Kecamatan Karangpilang yaitu sebesar 0,068\%. Deskripsi jumlah kasus HIV dan AIDS di Kota Surabaya tahun 2013 disajikan pada Tabel 2.

Tabel 2.

Deskripsi Variabel Penelitian

\begin{tabular}{crrrr}
\hline \hline Variabel & Rata-rata & \multicolumn{1}{c}{ Varians } & Minimum & Maksimum \\
& & & & \\
\hline $\mathrm{Y}_{1}$ & 13,9400 & 402,0600 & 0,0000 & 114,0000 \\
$\mathrm{Y}_{2}$ & 7,3550 & 27,3030 & 0,0000 & 24,0000 \\
$\mathrm{X}_{1}$ & 0,3414 & 0,0704 & 0,0046 & 1,2432 \\
$\mathrm{X}_{2}$ & 34,2000 & 62,2900 & 22,0800 & 53,2200 \\
$\mathrm{X}_{3}$ & 8,9000 & 0,7380 & 7,7770 & 11,2730 \\
$\mathrm{X}_{4}$ & 12,8700 & 73,7200 & 4,6900 & 40,6100 \\
$\mathrm{X}_{5}$ & 0,7690 & 0,5910 & 0,0680 & 3,2420 \\
\hline \hline
\end{tabular}

Penyebaran jumlah kasus HIV di Kota Surabaya disajikan pada Gambar 2. Berdasarkan Gambar 2, terdapat 22 kecamatan dengan jumlah kasus HIV kategori rendah yaitu Kecamatan Pakal, Sambikerep, Tandes, Asemrowo, Sukomanunggal, Bubutan, Simokerto, Kenjeran, Genteng,

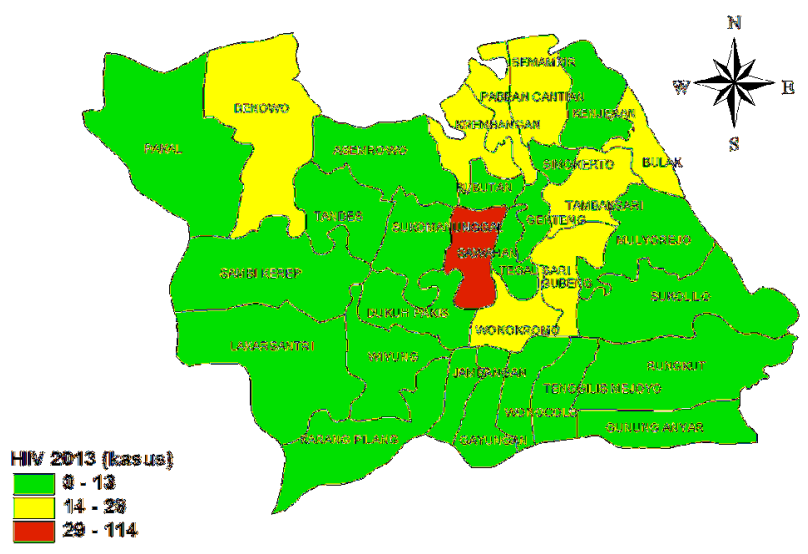

Gambar 2. Persebaran Jumlah Kasus HIV di Kota Surabaya.

Tegalsari, Lakar Santri, Dukuh Pakis, Wiyung, Karang Pilang, Jambangan, Wonocolo, Gayungan, Tanggilis Mejoyo, Gunung Anyar, Rungkut, Sukolilo dan Mulyorejo. Terdapat delapan kecamatan dengan jumlah kasus baru HIV kategori sedang yaitu Benowo, Krembangan, Pabean Cantikan, Semampir,
Bulak, Tambak Sari, Gubeng, dan Wonokromo. Kecamatan dengan jumlah kasus HIV kategori tinggi adalah Sawahan.

Rata-rata jumlah kasus AIDS di setiap kecamatan yang ada di Kota Surabaya pada tahun 2013 adalah sebanyak 7 kasus, kasus AIDS terbanyak adalah 24 kasus yang berada di Kecamatan Sawahan sementara di Kecamatan Sambikerep tidak ada kasus AIDS. Penyebaran jumlah kasus AIDS di Kota Surabaya disajikan pada Gambar 3. Berdasarkan Gambar 3 diperoleh 9 kecamatan dengan jumlah kasus AIDS kategori rendah yaitu Kecamatan Pakal, Sambikerep, Lakar Santri, Wiyung, Karang Pilang, Genteng, Jambangan, Gayungan dan Tenggilis Mejoyo. Terdapat 16 kecamatan dengan jumlah

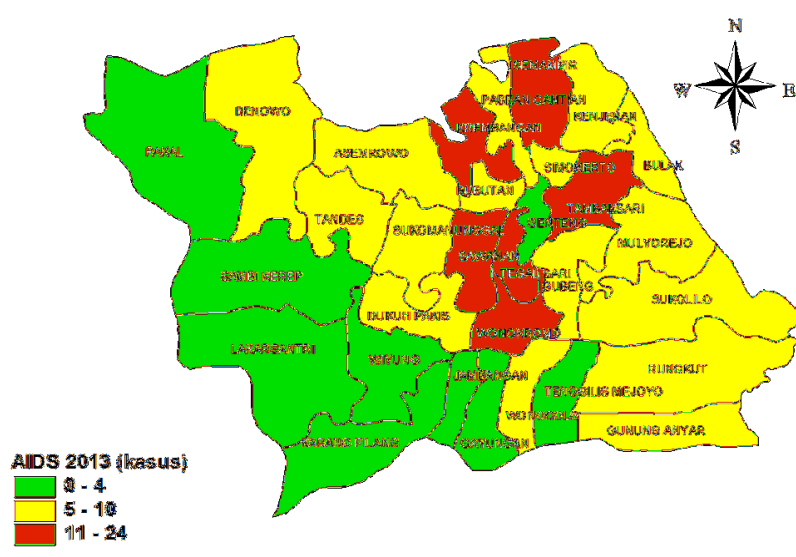

Gambar 3. Persebaran Jumlah Kasus AIDS di Kota Surabaya.

kasus AIDS kategori sedang yaitu Kecamatan Benowo, Tandes, Asemrowo, Sukomanunggal, Dukuh Pakis, Pabean Cantikan, Bubutan, Simokerto, Kenjeran, Bulak, Gubeng, Mulyorejo, Sukolilo, Rungkut, Wonocolo dan Gunung Anyar. Terdapat 6 kecamatan dengan jumlah kasus AIDS kategori tinggi yaitu Kecamatan Krembangan, Semampir, Tambaksari, Sawahan, Tegal Sari dan Wonokromo.

\section{B. Identifikasi Variabel Respon dan Prediktor}

Sebelum melakukan pemodelan BGPR langkah pertama yang dilakukan adalah uji korelasi variabel respon, karena pada pemodelan BGPR adanya hubungan linier (korelasi) yang erat antar variabel respon merupakan salah satu kriteria yang harus dipenuhi. Berdasarkan hasil analisis didapatkan nilai koefisien korelasi jumlah kasus HIV dan jumlah kasus AIDS sebesar 0,7790 artinya bahwa terdapat hubungan yang erat antara jumlah kasus HIV dan jumlah kasus AIDS. Pada hasil uji korelasi diperoleh $\left|t_{h i t}\right|$ sebesar 6,6904 lebih besar dari nilai $t_{(0,025 ; 29)}=2,0452$, maka tolak $\mathrm{H}_{0}$ atau dapat disimpulkan bahwa terdapat hubungan linier (korelasi) antara jumlah kasus HIV dan jumlah kasus AIDS.

Selanjutnya dilakukan pengujian distribusi bivariate generalized Poisson pada variabel respon. Berdasarkan hasil analisis diperoleh nilai $T_{h i t}=0,9651$ dan dengan menggunakan taraf signifikansi sebesar 0,05 diperoleh nilai $\chi_{(0,05 ; 2)}^{2}=5,9915$. Karena $T_{h i t}<\chi_{(0,05 ; 2)}^{2}$ maka gagal tolak $\mathrm{H}_{0}$ artinya bahwa jumlah kasus HIV dan jumlah kasus AIDS mengikuti distribusi bivariate generalized Poisson. Kemudian dilakukan pemeriksaan equidispersi, dari hasil analisis diperoleh nilai deviance/db untuk variabel respon $Y_{1}$ dan $Y_{2}$ berturut-turut adalah sebesar 14,3815 dan 3,9154 kedua nilai tersebut lebih 
besar dari satu, maka dapat disimpulkan bahwa jumlah kasus HIV dan jumlah kasus AIDS mengalami kasus overdispersi.

Tabel 3.

Nilai Korelasi dan VIF Variabel Prediktor

\begin{tabular}{ccccccc}
\hline \multicolumn{7}{c}{ Nilai Korelasi dan VIF Variabel Prediktor } \\
\hline $\begin{array}{c}\text { Vari- } \\
\text { abel }\end{array}$ & $\mathrm{X}_{1}$ & $\mathrm{X}_{2}$ & $\mathrm{X}_{3}$ & $\mathrm{X}_{4}$ & $\mathrm{X}_{5}$ & $\mathrm{VIF}$ \\
\hline $\mathrm{X}_{1}$ & 1 & & & & & 1,0732 \\
$\mathrm{X}_{2}$ & 0,17874 & 1 & & & & 1,4244 \\
$\mathrm{X}_{3}$ & 0,05469 & $-0,39450$ & 1 & & & 1,3585 \\
$\mathrm{X}_{4}$ & $-0,02553$ & 0,11067 & $-0,34533$ & 1 & & 1,1449 \\
$\mathrm{X}_{5}$ & $-0,05885$ & 0,34979 & $-0,11955$ & 0,10742 & 1 & 1,1702 \\
\hline \hline
\end{tabular}

Langkah terakhir adalah melakukan pemeriksaan multikolinieritas pada variabel prediktor, berdasarkan hasil analisis diperoleh bahwa nilai VIF untuk semua variabel prediktor yang digunakan adalah kurang dari 10, sehingga dapat disimpulkan bahwa tidak terjadi kasus multikolinieritas antar variabel prediktor yang digunakan pada penelitian. Untuk lebih rinci nilai korelasi dan VIF variabel prediktor disajikan pada Tabel 3.

\section{Model Bivariate Generalized Poisson Regression pada Model Terbaik}

Untuk mendapatkan model BGPR terbaik pada jumlah kasus

Tabel 4.

Nilai AIC Model Yang Signifikan pada Uji Serentak

\begin{tabular}{llll}
\hline \hline Variabe Prediktor & AIC & Variabel Prediktor & AIC \\
\hline $\mathrm{X}_{3}$ & 248,566 & $\mathrm{X}_{1}, \mathrm{X}_{3}, \mathrm{X}_{5}$ & 236,361 \\
$\mathrm{X}_{5}$ & 248,487 & $\mathrm{X}_{2}, \mathrm{X}_{3}, \mathrm{X}_{4}$ & 235,083 \\
$\mathrm{X}_{1}, \mathrm{X}_{3}$ & 240,635 & $\mathrm{X}_{2}, \mathrm{X}_{3}, \mathrm{X}_{5}$ & 236,976 \\
$\mathrm{X}_{2}, \mathrm{X}_{3}$ & 244,054 & $\mathrm{X}_{3}, \mathrm{X}_{4}, \mathrm{X}_{5}$ & 234,349 \\
$\mathrm{X}_{3}, \mathrm{X}_{4}$ & 239,378 & $\mathrm{X}_{1}, \mathrm{X}_{2}, \mathrm{X}_{3}, \mathrm{X}_{4}$ & 224,663 \\
$\mathrm{X}_{3}, \mathrm{X}_{5}$ & 243,569 & $\mathrm{X}_{1}, \mathrm{X}_{2}, \mathrm{X}_{3}, \mathrm{X}_{5}$ & 229,736 \\
$\mathrm{X}_{1}, \mathrm{X}_{2}, \mathrm{X}_{3}$ & 234,969 & $\mathrm{X}_{1}, \mathrm{X}_{3}, \mathrm{X}_{4}, \mathrm{X}_{5}$ & 226,661 \\
$\mathrm{X}_{1}, \mathrm{X}_{3}, \mathrm{X}_{4}$ & 230,656 & $\mathrm{X}_{1}, \mathrm{X}_{2}, \mathrm{X}_{3}, \mathrm{X}_{4}, \mathrm{X}_{5}$ & 220,038 \\
\hline \hline
\end{tabular}

HIV dan AIDS, maka dilakukan pemilihan model terbaik dari semua kemungkinan model yang mungkin terjadi berdasarkan nilai AIC. Model yang mungkin terjadi berdasarkan kombinasi variabel prediktor adalah sebanyak 31 model, namun model yang dibandingkan adalah model yang signifikan pada pengujian serentak saja. Terdapat 16 model BGPR yang signifikan pada pengujian serentak, untuk lebih rincinya disajikan pada Tabel 4.

Tabel 4 menunjukkan bahwa model yang memiliki AIC terkecil adalah model yang melibatkan semua variabel prediktor. Selanjutnya dilakukan pengujian parameter secara serentak pada model BGPR terbaik, pengujian secara serentak pada model BGPR bertujuan untuk mengetahui apakah variabel prediktor secara serentak berpengaruh signifikan terhadap model. Berikut adalah hipotesis yang digunakan pada pengujian parameter BGPR secara serentak:

$\mathrm{H}_{0}: \beta_{j 1}=\beta_{j 2}=\mathrm{L} \beta_{j 5}=0$ dan $\alpha_{1}=\alpha_{2}=0$

$\mathrm{H}_{1}$ : minimal ada satu dari $\beta_{j l} \neq 0$ dan $\alpha_{j} \neq 0 ; j=1,2$;

$$
l=1,2, \ldots, 5
$$

Berdasarkan hasil pemodelan BGPR diperoleh nilai devians dari model BGPR sebesar 28, hal ini berarti bahwa nilai devians lebih besar dari $\chi_{(0,05 ; 10)}^{2}=18,307$, sehingga diperoleh kesimpulan tolak $\mathrm{H}_{0}$ yang berarti bahwa paling sedikit ada satu variabel prediktor yang signifikan terhadap model. Estimasi parameter dari jumlah kasus HIV dan AIDS disajikan pada
Tabel 5. Model yang diperoleh dari hasil penaksiran parameter BGPR untuk jumlah kasus HIV dan AIDS didefenisikan pada persamaan 12 dan 13.

$$
\begin{aligned}
\ln \left(\hat{\mu}_{1}\right)= & 2,9880+0,7538 X_{1}+0,0376 X_{2}-0,1972 X_{3}+0,0008 X_{4} \\
& -0,3549 X_{5} \\
\hat{\mu}_{1}= & \exp \left(2,9880+0,7538 X_{1}+0,0376 X_{2}-0,1972 X_{3}\right. \\
& \left.+0,0008 X_{4}-0,3549 X_{5}\right) \\
\ln \left(\hat{\mu}_{2}\right)= & 0,5383-0,1584 X_{1}+0,0221 X_{2}+0,0593 X_{3}+0,0211 X_{4} \\
& -0,0919 X_{5} \\
\hat{\mu}_{2}= & \exp \left(0,5383-0,1584 X_{1}+0,0221 X_{2}+0,0593 X_{3}\right. \\
& \left.+0,0211 X_{4}-0,0919 X_{5}\right)
\end{aligned}
$$

Dari persamaan 12 diperoleh bahwa jika persentase penduduk yang tamat SMA $\left(\mathrm{X}_{2}\right)$ meningkat sebesar satu persen, maka akan meningkatkan rata-rata jumlah kasus HIV

Tabel 5.

Estimasi Parameter BGPR

\begin{tabular}{ccccc}
\hline \multirow{2}{*}{ Parameter } & \multicolumn{2}{c}{ Jumlah Kasus HIV } & \multicolumn{2}{c}{ Jumlah Kasus AIDS } \\
\cline { 2 - 5 } & Estimasi & SE & Estimasi & SE \\
\hline$\beta_{0}$ & 2,9880 & 1,0500 & 0,5383 & 1,2157 \\
$\beta_{1}$ & 0,7538 & 0,2053 & $-0,1584$ & 0,2966 \\
$\beta_{2}$ & 0,0376 & 0,0099 & 0,0221 & 0,0117 \\
$\beta_{3}$ & $-0,1972$ & 0,0953 & 0,0593 & 0,1090 \\
$\beta_{4}$ & 0,0008 & 0,0088 & 0,0211 & 0,0087 \\
$\beta_{5}$ & $-0,3549$ & 0,1005 & $-0,0919$ & 0,1109 \\
\hline \hline
\end{tabular}

sebesar $\exp (0,0376)=1,0383$ kali dari rata-rata jumlah kasus HIV semula dengan syarat variabel prediktor lainnya konstan. Dari persamaan 13 diperoleh bahwa setiap kenaikan satu persen penduduk pengguna kondom $\left(\mathrm{X}_{1}\right)$ di Kota Surabaya, maka akan menurunkan rata-rata jumlah kasus AIDS sebesar $\exp (-0,1584)=0,8535$ kali dari rata-rata jumlah kasus AIDS semula dengan syarat variabel prediktor lainnya konstan.

Berikutnya melakukan pengujian parsial terhadap parameter $\alpha$ dan $\beta$ yang bertujuan untuk mengetahui variabel prediktor mana yang berpengaruh secara signifikan terhadap model dengan hipotesis sebagai berikut.

$$
\begin{aligned}
& \mathrm{H}_{0}: \alpha_{j}=0 \\
& \mathrm{H}_{1}: \alpha_{j} \neq 0 ; j=1,2
\end{aligned}
$$

pengujian ini menggunakan statistik uji pada persamaan 7 yang kemudian dibandingkan dengan nilai $Z_{\text {tabel }} \cdot \mathrm{H}_{0}$ ditolak apabila $\left|Z_{\text {hit }}\right|>Z_{\text {tabel }}$, dengan menggunakan taraf signifikansi $5 \%$ diperoleh nilai $Z_{0,025}=1,96$. Berdasarkan hasil analisis diperoleh nilai $Z_{h i t}$ untuk parameter dispersi $\alpha_{1}$ dan $\alpha_{2}$ berturutturut adalah sebesar 62,1514 dan 30,9789. Kedua nilai tersebut lebih besar dari 1,96 , sehingga $\mathrm{H}_{0}$ ditolak artinya bahwa kedua parameter dispersi signifikan terhadap model BGPR jumlah kasus HIV dan AIDS di Kota Surabaya. Hipotesis untuk uji parsial parameter $\beta$ adalah sebagai berikut.

$$
\begin{aligned}
& \mathrm{H}_{0}: \beta_{j l}=0 \\
& \mathrm{H}_{1}: \beta_{j l} \neq 0 ; j=1,2 \text { dan } l=1,2, \ldots, 5
\end{aligned}
$$


Pengujian ini menggunakan statistik uji pada persamaan 8 yang kemudian dibandingkan dengan nilai $Z_{\text {tabel }} . \mathrm{H}_{0}$ ditolak apabila

Tabel 6.

Nilai $Z_{\text {hitung }}$ Model BGPR

\begin{tabular}{ccc}
\hline \hline Parameter & Jumlah Kasus HIV & Jumlah Kasus AIDS \\
\hline$\beta_{0}$ & 2,8457 & 0,4428 \\
$\beta_{1}$ & $3,6717^{*}$ & $-0,5341$ \\
$\beta_{2}$ & $3,7980^{*}$ & 1,8889 \\
$\beta_{3}$ & $-2,0693^{*}$ & 0,5440 \\
$\beta_{4}$ & 0,0909 & $2,4253^{*}$ \\
$\beta_{5}$ & $-3,5313^{*}$ & $-0,8287$ \\
\hline \hline
\end{tabular}

$\left|Z_{\text {hit }}\right|>Z_{\text {tabel }}$, dengan menggunakan taraf signifikansi $5 \%$ diperoleh nilai $Z_{0,025}=1,96$. Nilai $\left|Z_{h i t}\right|$ pada uji parsial parameter $\beta$ disajikan pada Tabel 6 .

Berdasarkan Tabel 6 diperoleh bahwa variabel prediktor yang berpengaruh signifikan terhadap model BGPR jumlah kasus HIV di Kota Surabaya adalah persentase penduduk pengguna kondom, persentase penduduk yang tamat SMA, persentase penduduk kelompok umur 25-29 tahun dan persentase kegiatan penyuluhan kesehatan masyarakat. Sedangkan variabel prediktor yang berpengaruh secara signifikan terhadap model BGPR jumlah kasus AIDS di Kota Surabaya adalah persentase penduduk yang memiliki jaminan kesehatan masyarakat miskin.

\section{KESIMPULAN DAN SARAN}

\section{A. Kesimpulan}

Kesimpulan yang dapat diambil dari penelitian adalah sebagai berikut.

1. Jumlah kasus HIV terbanyak di Kota Surabaya berada di Kecamatan Sawahan dengan jumlah kasus sebanyak 114 kasus, sementara di Kecamatan Lakar Santri tidak teradapat kasus HIV. Jumlah kasus AIDS terbanyak berada di Kecamatan Sawahan, sementara di Kecamatan Sambikerep tidak terdapat kasus AIDS.

2. Berdasarkan nilai AIC diperoleh bahwa model terbaik adalah model yang melibatkan semua variabel prediktor pada pemodelan BGPR dengan nilai AIC sebesar 220,038. Adapun variabel prediktor yang berpengaruh signifikan terhadap model jumlah kasus HIV adalah persentase penduduk pengguna kondom, persentase penduduk yang tamat SMA, persentase penduduk kelompok umur 25-29 tahun dan persentase kegiatan penyuluhan kesehatan masyarakat. Sedangkan variabel yang berpengaruh signifikan terhadap model jumlah kasus AIDS adalah persentase penduduk yang memiliki jaminan kesehatan masyarakat miskin.

\section{B. Saran}

Berdasarkan hasil analasis maka saran yang dapat peneliti berikan adalah untuk penelitian selanjutnya, karena data baru tentang variabel yang digunakan dalam penelitian ini tidak tersedia di Dinas Kesehatan Kota Surabaya maka sebaiknya melakukan penelitian tentang HIV dan AIDS menggunakan data primer. Bagi Dinas Kesehatan Kota Surabaya perlu memprioritaskan kegiatan penyuluhan kesehatan masyarakat terutama tentang penyakit HIV dan AIDS, karena dengan pemahaman dan pengetahuan yang mumpuni tentang HIV dan AIDS maka masyarakat akan lebih waspada dalam melakukan hubungan seksual terutama bagi penduduk yang memiliki pasangan seksual lebih dari satu orang sehingga diharapkan mampu menekan jumlah kasus HIV dan AIDS di Kota Surabaya. Dinas Kesehatan Kota Surabaya perlu melakukan pemeriksaan ulang, apakah pemberikan jaminan kesehatan masyarakat miskin telah tepat sasaran atau tidak.

\section{DAFTAR PUSTAKA}

[1] Kementrian Kesehatan RI, "Situasi dan Analisis HIV AIDS," Jakarta, 2014.

[2] Dinas Kesehatan Kota Surabaya, "Profil Kesehatan Kota Surabaya," 2015.

[3] M. P. Putri, "Pemodelan Jumlah Kematian Ibu dan Jumlah Kematian Bayi di Provinsi Jawa Tengah Menggunakan Bivariate Generalized Poisson Regression," Surabaya, 2017.

[4] D. K. Wardani, "Pendugaan Parameter dan Pengujian Hipotesis Bivariate Generalized Poisson Regression," Surabaya, 2016.

[5] R. Vernic, "On The Bivariate Generalized Poisson Distribution," J. IAA, vol. 27, no. 1, pp. 23-32, 1997.

[6] A. Agresti, Categorical Data Analysis, 2nd ed. New York: John Wiley \& Sons, Inc, 2002

[7] R. Hocking, Methods and Application of Linear Models. Canada: John Wiley and Sons, Inc, 2003.

[8] F. Famoye, J. T. Wulu, and K. P. Singh, "On the Generalized Poisson Regression Model with an Application to Accident Data," J. Data Sci., vol. 2, pp. 287-295, 2004.

[9] R. A. Johnson and D. W. Wichern, Applied Multivariate Statistical Analysis. New Jersey: Pearson education, Inc., 2007. 